Review

\title{
Novel coronavirus infection in the Eastern Mediterranean Region: time to act
}

M.R. Malik, ${ }^{7}$ A.R. Mafi, ${ }^{1}$ J. Mahjour, ${ }^{2}$ M. Opoka, ${ }^{7}$ M. Elhakim ${ }^{7}$ and M.O. Muntasir ${ }^{1}$

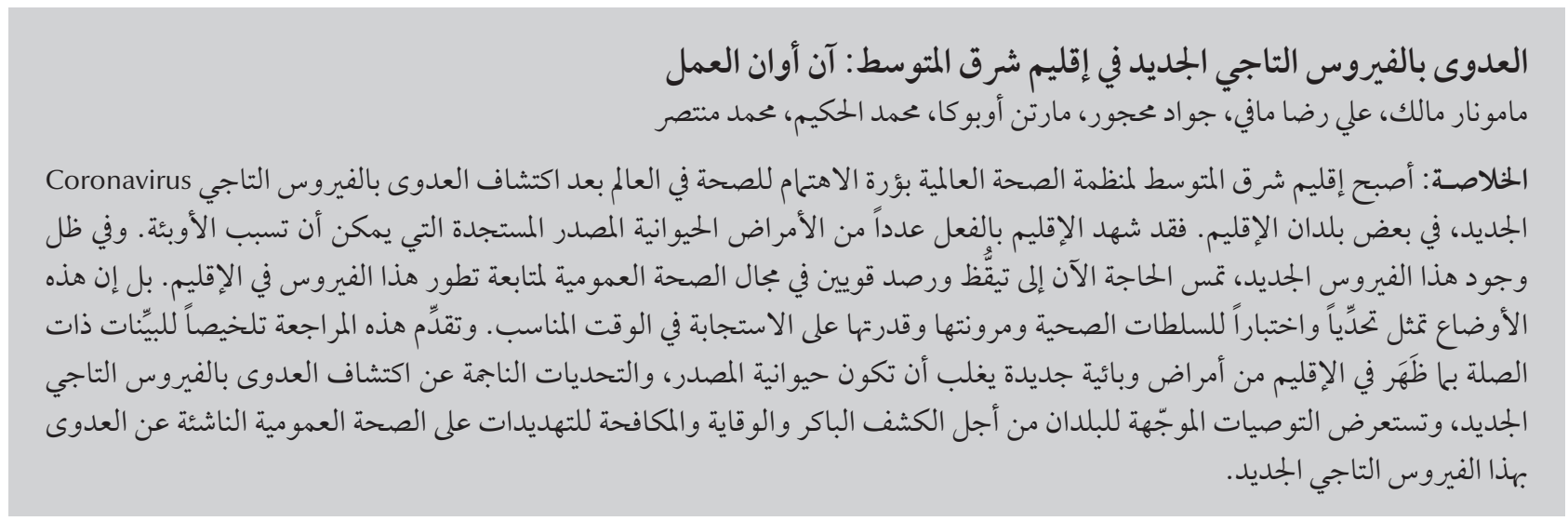

ABSTRACT The Eastern Mediterranean Region of World Health Organization has been an emerging focus for global health after the discovery of a novel coronavirus infection in some countries in the Region. The Region has already witnessed a number of emerging zoonoses with epidemic potential. In view of this new virus, there is now an urgent need for strong public health vigilance and monitoring of the evolution of the virus in the Region. The situation will challenge and test the national health authorities' resilience and ability to respond in a timely manner. This review summarizes the evidence related to the emergence in the Region of new epidemic diseases of predominantly zoonotic origin and the challenges posed by the discovery of the novel coronavirus infection, and outlines recommendations for the countries for early detection, prevention and control of public health threats from this novel coronavirus infection.

\section{Infection par le nouveau coronavirus dans la Région de la Méditerranée orientale : I'heure est à l'action}

RÉSUMÉ La Région de la Méditerranée orientale de l'Organisation mondiale de la Santé est progressivement devenue un centre d'attention en matière de santé mondiale après la découverte d'une infection par un nouveau coronavirus dans certains pays de la Région. La Région a déjà connu un certain nombre de zoonoses émergentes à potentiel épidémique. Face à ce nouveau virus, une grande vigilance en matière de santé publique et une surveillance de l'évolution du virus dans la Région sont maintenant nécessaires de manière urgente. Cette situation risque de mettre à l'épreuve les capacités de résilience et de riposte rapide des autorités sanitaires nationales. Le présent article synthétise les données concernant l'émergence dans la Région de nouvelles maladies épidémiques, principalement d'origine zoonotique, et les difficultés découlant de la découverte de cette infection par un nouveau coronavirus. Il esquisse en outre des recommendations à l'intention des pays pour le dépistage précoce et la prévention de l'infection par le nouveau coronavirus et l'endiguement de la menace qu'elle représente pour la santé publique. 


\section{Introduction}

The Eastern Mediterranean Region of the World Health Organization (WHO) comprises 22 Member States and the occupied Palestinian territory and is home to over 583 million people [1]. The Region extends from Pakistan in the east to Morocco in the west and as far south as Somalia and as far north as the Islamic Republic of Iran.

Although the countries of the Region share many common elements of history and culture, the Region abounds with sociopolitical contrast and contradictions. There is wide variation in the gross national income (GNI) per capita among the countries [2]. Such variation and income disparities have a major influence on overall health spending and a significant impact on current health achievements in the Region.

The geopolitical situation of the Regionis extremely challenging sincemany countries are in a state of protracted humanitarian emergencies or recovering from conflict. Providing emergency medical assistance to these countries has become a normative function of the WHO's Regional Office for Eastern Mediterranean in recent years [3]. Over the past decade, the Region has faced repeated outbreaks from emerging infectious diseases as a result of various factors [4]. International travel either for tourism, business or religious reasons, globalization and the varying capacity of surveillance systems in the countries in the Region to detect and diagnose early an unknown pathogen are significant risk factors for rapid international spread of any emerging infections once such infections or diseases emerge in the Region. Certain disease amplifiers, such as population movement, fragmented health systems, weak response and laboratory diagnostic capacity, and disruption of routine public health services in crisis-affected countries, have also contributed considerably to the surge of emerging infectious diseases in the Region [5].
In this paper, we summarize the evidence related to emergence of new epidemic diseases in our Region that are predominantly zoonotic in origin and the challenges posed by the discovery of a novel coronavirus infection in the Region, and outline some specific recommendations for the countries for early detection and prevention of public health threats from this novel coronavirus infection.

\section{Emerging infectious disease in EMR}

The Region presents daunting health challenges in the field of emerging zoonoses. Evidence shows that over $60 \%$ of the emerging infectious diseases that have been identified since 1940 are zoonotic [6] and thus the Region continues to witness both sporadic and epidemic occurrence of emerging zoonoses (Table 1).

The Region has recently seen outbreaks of yellow fever in Sudan [7], Chikungunya in Yemen [8], West Nile fever in Tunisia [9] and Q fever in Afghanistan [10,11] and Iraq [12]. The region is home to a number of arbo and filoviruses. While outbreaks from Crimean-Congo haemorrhagic fever (CCHF) occur periodically in Afghanistan [13], Islamic Republic of Iran [14] and Pakistan [15-18], nosocomial outbreaks of the disease have been reported in recent years as a seasonal surge in Iraq [16], United Arab Emirates [18] and Sudan [19-21]. Viral haemorrhagic fevers are perpetual risks in the Region. Ebola haemorrhagic fever in South Sudan in 2004 was the only viral haemorrhagic fever caused by a filovirus seen the Region $[22,23]$. The sudden expansion of Rift Valley fever, endemic in sub-Saharan Africa, along the animal trade routes to Yemen [24], Saudi Arabia [25,26] and Sudan [27], is a characteristic example of geographic expansion of emerging zoonoses in the Region.
The highly pathogenic avian influenza spread rapidly through the Region in 2006 with large epizootics reported in a number of countries while human infections occurred in Djibouti [28], Iraq [29], Pakistan [30] and Egypt [31]. Avian influenza is now presumed entrenched in Egypt with a low level of transmission throughout the year [32]. In 2009, the influenza A (H1N1)pdm 09 of swine origin affected all countries in the Region [33]. Other emerging zoonotic diseases have occurred in the Region and, while rare, can still cause high morbidity. These include monkey pox [34], sandfly fever [35] and plague [36]. As illustrated by the Alkhurma virus, this Region is also home to newly emerging pathogens of zoonotic origin [37-39]. In the midst of the occurrence of these old and new infectious diseases seen by the world in the past decade, severe acute respiratory syndrome (SARS) was the only emerging zoonoses that did not strike the Region in 2003.

\section{Novel coronavirus infections in EMR}

As if to remind the Region that emerging zoonoses can occur anywhere anytime and that no country is immune to the threats of these diseases, human infection with a novel coronavirus $(\mathrm{nCoV})$ arose in the Region in 2012 and rapidly focused global attention on this new virus [40]. First detected in a Saudi Arabian national in September 2012 who had died of acute respiratory illness in June, it was soon confirmed in a patient from Qatar in London in October 2012 with similar illness [41]. In November, two laboratory-confirmed cases were reported retrospectively by diagnosis of stored respiratory and serum specimens of two deceased patients in Jordan with an occurrence date in March-April 2012 from a cluster of healthcare workers whose initial diagnosis was 
Table 1 Selected outbreaks from emerging zoonoses in the Eastern Mediterranean Region of World Health Organization, 2000-March 2013

\begin{tabular}{|c|c|c|c|c|c|c|}
\hline \multirow[t]{2}{*}{ Disease } & \multirow[t]{2}{*}{ Country } & \multirow[t]{2}{*}{ Period } & \multirow[t]{2}{*}{ Host/reservoir } & \multicolumn{2}{|c|}{$\begin{array}{l}\text { Human health } \\
\text { impact }\end{array}$} & \multirow[t]{2}{*}{ References } \\
\hline & & & & Cases $^{\mathrm{a}}$ & Deaths & \\
\hline \multirow{3}{*}{ Rift Valley fever } & Yemen & $\begin{array}{c}10 \text { Sep- } \\
19 \text { Oct } 2000\end{array}$ & \multirow{3}{*}{$\begin{array}{l}\text { Cattle, sheep, goats; } \\
\text { Aedes mosquitoes } \\
\text { (vector) }\end{array}$} & 653 & 80 & 24 \\
\hline & Saudi Arabia & $\begin{array}{l}26 \text { Aug 2000- } \\
22 \text { Sep } 2001\end{array}$ & & 886 & 123 & 25,26 \\
\hline & Sudan & $\begin{array}{l}18 \text { Oct } 2007- \\
15 \text { Jan } 2008\end{array}$ & & 747 & 230 & 27 \\
\hline \multirow{4}{*}{$\mathrm{CCHF}$} & Pakistan $^{\mathrm{b}}$ & 2000-2012 & \multirow{4}{*}{$\begin{array}{l}\text { Wild and domestic } \\
\text { animals (cattle, } \\
\text { goats and sheep); } \\
\text { Hyalomma ticks }\end{array}$} & 585 & 113 & $15-18$ \\
\hline & $\operatorname{Iran}(I R)^{b}$ & 2000-2011 & & 3235 & 122 & 14 \\
\hline & Afghanistan $^{b}$ & 2007-2012 & & 104 & 15 & 13 \\
\hline & Sudan ${ }^{c}$ & 2007-2011 & & & & $19-21$ \\
\hline \multirow{3}{*}{ Yellow fever } & \multirow{2}{*}{ Sudan } & Sep-Dec 2005 & \multirow{3}{*}{$\begin{array}{l}\text { Primates (mainly } \\
\text { monkeys); Aedes } \\
\text { mosquitoes (vector) }\end{array}$} & 605 & 163 & 59 \\
\hline & & 02 Sep-24 Dec 2012 & & 849 & 171 & 7 \\
\hline & South Sudan & May-Jun 2003 & & 178 & 27 & 60 \\
\hline $\begin{array}{l}\text { Ebola haemorrhagic } \\
\text { fever }\end{array}$ & South Sudan & 24 May-26 Jun 2004 & Monkeys & 17 & 7 & 22,23 \\
\hline Monkey pox & Sudan, Unity State & $\begin{array}{l}20 \text { Sep 2005- } \\
31 \text { Jan } 2006\end{array}$ & $\begin{array}{l}\text { Unknown but } \\
\text { rodents, sun squirrels, } \\
\text { even monkeys are } \\
\text { implicated }\end{array}$ & 49 & 0 & 34 \\
\hline $\begin{array}{l}\text { Al-Khurma } \\
\text { haemorrhagic } \\
\text { fever }^{d}\end{array}$ & Saudi Arabia & 2001-2009 & $\begin{array}{l}\text { Camels and sheep; } \\
\text { Mammalian ticks }\end{array}$ & & & $37-39$ \\
\hline Sandfly fever & Lebanon & 01 Jul-18 Sep 2007 & $\begin{array}{l}\text { Phlebotomine } \\
\text { sandflies }\end{array}$ & 800 & - & 35 \\
\hline \multirow{4}{*}{$\begin{array}{l}\text { Avian influenza } \\
(\mathrm{H} 5 \mathrm{~N} 1)^{\mathrm{e}}\end{array}$} & Iraq & Jan-Mar 2006 & \multirow{4}{*}{$\begin{array}{l}\text { Poultry, birds, wild } \\
\text { fowl }\end{array}$} & 3 & 2 & 29 \\
\hline & Djibouti & 23 Apr 2006 & & 1 & - & 28 \\
\hline & Pakistan & 29 Oct-21 Nov 2007 & & 4 & 2 & 30 \\
\hline & Egypt & Jan 2006-Mar 2013 & & 172 & 62 & 32 \\
\hline Plague & Libya & 09-18 Jun 2009 & Rodents; fleas & 5 & 1 & 36 \\
\hline Pandemic influenza & All countries & $\begin{array}{l}25 \text { May 2009- } \\
6 \text { Aug } 2010\end{array}$ & Birds; pigs & & 1019 & 33 \\
\hline Q fever ${ }^{f}$ & Afghanistan & 29 May-02 Jun 2011 & $\begin{array}{l}\text { Domestic animals } \\
\text { (sheep, cattle, goats); } \\
\text { birds }\end{array}$ & 147 & & f \\
\hline Chikungunya & Yemen & Oct 2010-Mar 2011 & $\begin{array}{l}\text { Monkeys; Aedes } \\
\text { mosquitoes (vector) }\end{array}$ & 1657 & 0 & 8 \\
\hline $\begin{array}{l}\text { West Nile virus } \\
\text { fever }\end{array}$ & Tunisia & 14 Aug-14 Nov 2012 & $\begin{array}{l}\text { Birds; mosquitoes } \\
\text { (vector) }\end{array}$ & 63 & 10 & 9 \\
\hline $\begin{array}{l}\text { Novel coronavirus } \\
\text { infection }\end{array}$ & $\begin{array}{c}\text { Saudi Arabia, Qatar, } \\
\text { Jordan, UAE }\end{array}$ & $\begin{array}{l}21 \text { Mar 2012-30 Apr } \\
2013\end{array}$ & $\begin{array}{l}\text { Unknown but bats are } \\
\text { suspected }\end{array}$ & 14 & 9 & 43 \\
\hline
\end{tabular}

asuspected cases including those laboratory-confirmed.

${ }^{b}$ Cases reported during the outbreak are included.

'Nosocomial transmission.

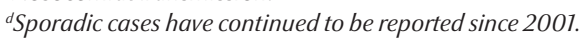

eLaboratory-confirmed cases.

fWorld Health Organization. Eastern Mediterranean Regional Office. Weekly Epidemiological Monitor, 2011, $5(28$ \& 29).

$C C H F=$ Crimean-Congo haemorrhagic fever; $U A E=$ United Arab Emirates. 
inconclusive [42]. On 26 March 2013, Germany notified WHO of an imported case of novel coronavirus infection from the United Arab Emirates [43]. By the end of March 2013, of the 17 laboratory-confirmed cases of $\mathrm{nCoV}$ infections, including 10 deaths, that were reported to WHO globally [43], 14 cases (82\%), including 9 deaths (90\%), were reported from four countries in the Region (Jordan, Saudi Arabia, Qatar and the United Arab Emirates) (Figure 1).

It is unclear where the initial infection occurred. In the cluster of healthcare workers in Jordan, the date of onset of symptoms of a confirmed case was in March 2012, while at least three other cases reported in $2013 \mathrm{had}$ a history of travel to another country (including Pakistan and Egypt) where cases have not been reported previously [44]. The majority of cases reported in the Region are male (12 out of 14) and the cases reported so far show preponderance among older age groups (Table 2).

Most cases have been sporadic. However, by March 2013, limited human-to-human transmission had been noted within a household setting in
Saudi Arabia and in a healthcare setting in Jordan [44].

\section{Risk assessment and mitigation}

The appearance of a new disease in the Region that had not been seen before and about which little was known of its origin or mode of transmission [44] may constitute a serious worldwide threat with profound implications for global health security. The Region, especially the countries where these novel coronavirus infections occurred, is a favourite destination for millions of tourists and religious pilgrims coming from outside the Region and hence represents a substantial risk and major conduit for the global spread of diseases as has been seen with the outbreak of meningococcal meningitis W135 in 2000 and 2001 [45] and cholera in 1984-1986 [46].

Religious mass gatherings like the Hajj pilgrimage in Saudi Arabia is the largest annual religious mass gathering worldwide with over 3 million people performing the Hajj every year [44]. Also over six million Umrah pilgrims visit Saudi Arabia every year. The countries reporting the $\mathrm{nCoV}$ infections are

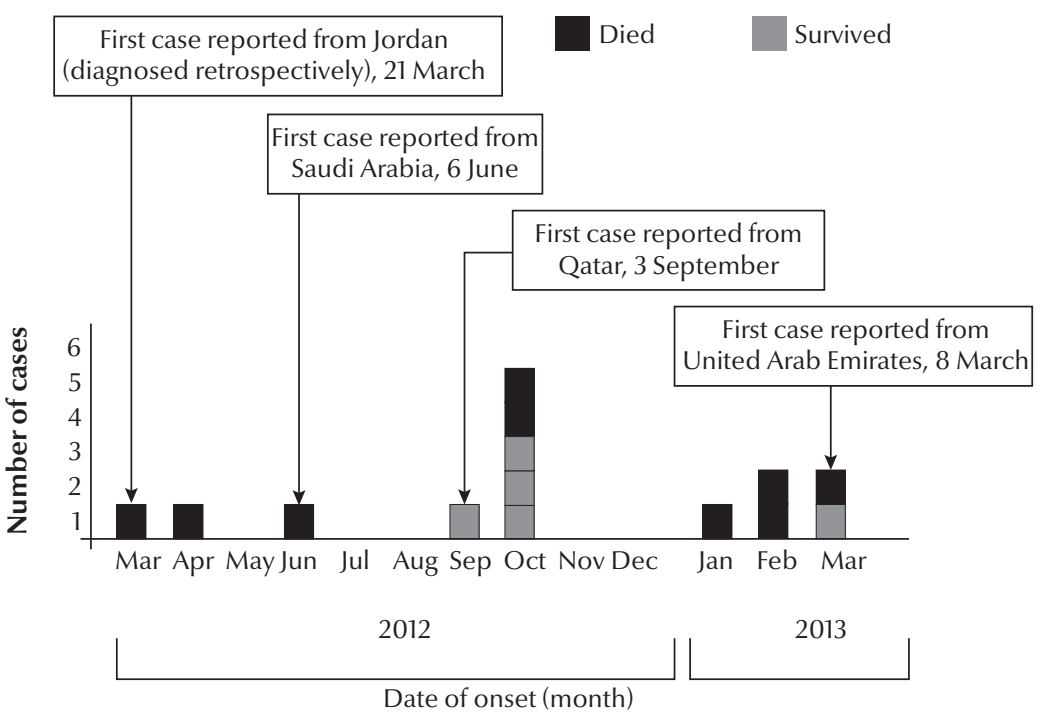

Figure 1 Epidemic curve of confirmed cases of novel coronavirus infection in the Eastern Mediterranean Region, March 2012-March 2013 also home to large numbers of migrant populations from Asia and Africa. A more cautious approach is therefore needed to understand fully the global threat posed by this novel virus for international spread.

Of the total cases reported in the Region, five were sporadic with no secondary transmission, while the remainder occurred in two clusters, two cases in one cluster in an intensive care unit in Jordan [42] and others in a family cluster in Saudi Arabia [44]. Investigations around previous clusters and cases have not demonstrated onward transmission or increases in rates of severe disease in the area [47]. The fact that this is a new virus and an animal origin is presumed $[41,47]$ and that the mortality rate was high amongst the confirmed cases, it appears that people of all ages may have little protective immunity. As such, the global pandemic threat associated with this virus should not be understated. The ability of this virus to spread beyond first or second generation should be closely monitored and tracked. The mild presentation and the uncertainty around exposure raise concern that other mild infections and links might have been missed. It is not clear if or when the low levels of sporadic transmission currently seen with this virus will change. In the current situation, there is a need to constantly assess and monitor the evolving threats from this new disease. The only way this can be achieved is through early detection of any unusual patterns in the disease manifestations that can spread on a global scale and by adequate and timely sharing of such disease patterns.

\section{Surveillance}

From the public health perspective, all countries of the Region need to enhance their surveillance for severe acute respiratory infections (SARI). In countries where routine surveillance for SARI may be too resourceintensive, an alternative "best buy" 
can be a sentinel-based surveillance system for SARI in a geographically representative area combined with appropriate strategies for routine collection and rapid laboratory testing of samples to confirm or rule out any circulating $\mathrm{nCoV}$ and immediate notification of WHO of any new or untypeable respiratory pathogen. Any unusual cluster of acute respiratory disease needs to be reported to $\mathrm{WHO}$ promptly as well. The countries of the Region where cases have occurred or have been linked to in the past need to establish case-based surveillance for SARI and conduct universal screening of SARI patients for $\mathrm{nCoV}$ using the latest WHO case definition [48] to determine if the virus is still circulating and the extent of its distribution. From the global perspective, the key would be to detect early any event that signals sustained secondary or tertiary transmission in the community.

\section{Laboratory tests}

The prompt recognition of $\mathrm{CoV}$ infections will largely depend on the laboratory capacity of the countries to detect and identify such novel pathogens in a timely manner. Epidemiological surveillance for SARI will be meaningful only when the laboratory can test the patient's respiratory specimens routinely and detect any emerging new pathogen. Specific laboratory testing procedures for $\mathrm{nCoV}$ have been published [49]. Capacities need to be increased rapidly in all countries for routine confirmation of cases of novel coronavirus infection.

\section{Investigation of cases and close contacts}

A standardized approach for fullscale epidemiological investigation needs to be instituted as soon as any case is confirmed. The close contacts (households or healthcare provider) need to be identified and followed up for at least 10 days, which is the putative incubation period for $\mathrm{nCoV}$ infection. If respiratory illness occurs within the 10 days after last exposure in a close contact, the contact should be investigated urgently for $\mathrm{nCoV}$ infection. Such investigation is important to help understand the spectrum of illness and risk of infection in those exposed.

\section{Infection prevention and control during healthcare}

The current global knowledge on the risk of transmission of $\mathrm{CoV}$ in healthcare settings is limited and based on a small number of cases reported so far globally. However as there is now evidence of limited human-tohuman transmission, in at least two healthcare settings possibly involving different modes of transmission [50], strict infection control measures need to be rapidly applied to prevent onward transmission that may be associated with health care. The successful prevention of amplification of $\mathrm{nCoV}$ infections associated with health care will depend on the full implementation of the core components for Infection Prevention and Control programmes [51] including standard precautions. Additional precautions while caring for patients with probable or confirmed infection with $\mathrm{nCoV}$ should depend on risk assessment especially when aerosol-generating procedures are being performed.

\section{Clinical care}

No recognized effective treatment is yet available for $\mathrm{nCoV}$ infection [50]. Possible interventions that need to be investigated include convalescent plasma from recovered cases. The premise of this approach is based on some evidence from the treatment of cases with severe acute respiratory virus infection caused by SARS-CoV [52], highly pathogenic avian influenza A (H5N1) [53] and most recently by the 2009 pandemic influenza virus [54]. This will require that affected countries, WHO and the WHO Collaborating Centres work together to establish an international novel coronavirus convalescent plasma centre that can strengthen the Region's public health preparedness against

Table 2 Characteristics of 14 confirmed cases of nCoV including 9 deaths in the Eastern Mediterranean Region, March 2012March 2013

\begin{tabular}{|c|c|c|c|c|c|c|c|}
\hline \multirow{2}{*}{ Age group (years) } & \multicolumn{2}{|c|}{ Sex } & \multirow[t]{2}{*}{ Acute renal failure $^{b}$} & \multirow[t]{2}{*}{ Comorbidities $^{c}$} & \multicolumn{3}{|c|}{ Outcome } \\
\hline & Male & Female & & & Died & Recovered & $\begin{array}{c}\text { Still } \\
\text { hospitalized }\end{array}$ \\
\hline $25-34$ & 2 & & & & 1 & 1 & \\
\hline $35-44$ & 2 & 1 & 1 & & 3 & & \\
\hline $45-54$ & 3 & & 2 & 2 & & 2 & 1 \\
\hline $55-64$ & 1 & 1 & 1 & & 2 & & \\
\hline $65+$ & 4 & & 2 & 1 & 3 & 1 & \\
\hline Total & 12 & 2 & 6 & 3 & 9 & 4 & 1 \\
\hline
\end{tabular}

${ }^{a}$ No cases have been found in people under 25 years of age.

bInformation for the remaining cases are not available.

${ }^{c}$ Comorbidities include pre-existing chronic health conditions such as diabetes, chronic kidney disease, heart disease, lung disease, multiple myeloma, etc. 
this infection. The countries may also benefit from the interim rapid advice document published by WHO [53] for care of patients, which may need to be adapted to the local settings.

\section{Transparency in sharing information}

The emergence of any new infectious disease, particularly one with the capacity to transmit from personto-person, creates several challenges. Transparency of the countries where $\mathrm{nCoV}$ cases have occurred or are likely to occur in the future will be central to our understanding of how this virus transcends into a pandemic threat. Greater understanding of the epidemiology of and disease manifestations caused by the virus can only help to determine the evolving risk to global health associated with this novel virus. As such information is critical to global health security, countries need to use to the full all the mechanisms enshrined in the framework of the International Health Regulations (IHR) (2005) [55] for their benefit. The IHR (2005) also underscores the importance of minimizing adverse publicity effects or unfair and unwarranted treatment of affected countries.

\section{Risk communication}

The initial days surrounding any outbreak of a novel disease is challenging as knowledge about its epidemiology is minimal, accurate predictions are difficult and have to rely on historical events that parallel the diseases as closely as possible [56]. As these days are usually marked by confusion, uncertainty and a sense of urgency, good and effective communication is with the media as well as the general public in order to increase public trust and confidence on the measures taken by the national health authorities to protect the health of their population. Risk communication needs to an integral part of control efforts because with good communication, support can be galvanized, the public can be reassured and information that may save lives can be provided. As much as good communication can mobilize public support and increase credibility, there have been numerous communication failures that have delayed outbreak control and as a result prolonged economic and social turmoil [56].

\section{Seroepidemiological studies}

Many questions about this novel coronavirus remain unanswered. One assumption that the virus was circulating in one or more animal groups, yet remained unrecognized for some time, and is transmitted sporadically to humans as a zoonotic infection $[44,50]$ needs to be studied in-depth. Although all cases to date have had some connection with the Arabian Peninsula, more information is needed about the full geographical extent of the virus. Serological studies for the virus are urgently needed to accurately assess sub-clinical infection rates (both mild and asymptomatic infections) in countries where cases have occurred, and large multicountry serosurveys need to be conducted to better understand the epidemiology and geographic extent of the infection. Controlled studies of cases and contacts can also give a clue to the source of infection [44]. Several laboratories are currently working to develop and validate serological assays for $\mathrm{nCoV}$. Two approaches for serological testing have recently been published $[57,58]$. Further validated assays and protocols for serosurvey need to be developed and applied in all countries in a standard way.

\section{Conclusion and future perspective}

The Region has borne the brunt of several emerging infectious diseases of zoonotic origin and is now a focus for global health after the discovery of $\mathrm{nCoV}$. A lesson of this experience is that emerging infectious diseases that are of zoonotic origin are unexpected and unpredictable events. Another lesson that has been learned is that any disease outbreak anywhere today could be a problem for the world tomorrow. These novel diseases will continue to confront and challenge national health authorities' resilience and responsiveness. Likewise, the ability of regional and global communities to cooperate to control these diseases that cross national boundaries will be a real test for global health security.

What is important now is not to lower our guard and to continue to assess the risk of global threats associated with emergence of this novel virus. This will involve close regional collaboration between the countries where cases have occurred, $\mathrm{WHO}$ and other international health bodies who are also responsible for global health. While the global efforts should continue to fill the current gaps in knowledge associated with this virus, much greater regional cooperation is needed to protect the health of the people living in the Region. From the regional perspective, the present situation should not be treated as just a sequel to the long list of epidemic zoonotic diseases that the Region has witnessed in the past decade or so. It should trigger a clear need for the detection, prevention and control of this and other emerging zoonoses in the Region that may cross borders. In the mean time, one can only hope that this new virus does not unfold into one that is easily transmissible between humans. 


\section{References}

1. World Health Organization. Eastern Mediterranean Regional Office. About us. Available from http://www.emro.who.int/ entity/about-us/.

2. World Bank. World Development Indicators. Available from http://data.worldbank.org/

3. Shaping the future of health in the WHO Eastern Mediterranean Region: reinforcing the role of WHO. Cairo, World Health Organization Regional Office for the Eastern Mediterranean, 2012 (http://applications.emro.who.int/dsaf/EMROPUB_2012_ EN_742.pdf, accessed 9 May 2013).

4. Report on the Meeting on establishing an outbreak alert and response network in the Eastern Mediterranean Region Casablanca, Morocco 21-23 October 2012. Cairo, World Health Organization Regional Office for the Eastern Mediterranean, 2013 (http://applications.emro.who.int/docs/IC_Meet_ Rep_2013_EN_14863.pdf, accessed 9 May 2013).

5. Growing threat of viral haemorrhagic fevers in the Eastern Mediterranean Region: a call for action. World Health Organization Regional Office for the Eastern Mediterranean (Technical paper EM/RC54/5) (http://applications.emro.who.int/docs/ EM_RC54_5_en.pdf, accessed 9 May 2013).

6. Jones KE, Patel N, Levy M, et al. Global trends in emerging infectious diseases. Nature 2008, 451:990-994.

7. Markoff, L. Yellow fever outbreak in Sudan. New England Journal of Medicine, 2013, 368(8):689-691.

8. Zayed A et al. Detection of Chikungunya virus in Aedes aegypti during 2011 outbreak in Al Hodayda, Yemen. Acta Tropica, 2012, 123(1):62-66.

9. Report of new health events occurring inside the Episouth area. Tunisia. EpiSouth Weekly Epi Bulletin, No. 243 (7 November-14 November 2012) (http://www.episouthnetwork.org/ sites/default/files/bulletin_file/eweb_243_15_11_12.pdf, accessed 9 May 2013).

10. Aronson NE. Infections Associated with War: the American Forces Experience in Iraq and Afghanistan. Clinical Microbiology Newsletter, 2008, 30(18):135-140.

11. Hartzell JD et al. Atypical Q fever in US soldiers. Emerging Infectious Diseases, 2007, 13(8):1247-1249.

12. Leung-Shea C, Danaher PJ. Q Fever in Members of the United States Armed Forces Returning from Iraq. Clinical Infectious Diseases, 2006, 43(8):e77-e82.

13. Mofleh J, Ahmad AZ. Crimean-Congo haemorrhagic fever outbreak investigation in the Western Region of Afghanistan in 2008. Eastern Mediterranean Health Journal, 2012, 18(5):522-526.

14. Chinikar $\mathrm{S}$ et al. Crimean-Congo Hemorrhagic Fever (CCHF). In: Lorenzo-Morales J, ed. Zoonosis. InTech, 2012 (http://www.intechopen.com/books/zoonosis/crimeancongo-hemorhagic-fever-, accessed 10 May 2013) (DOI: 10.5772/38851).

15. Sheikh AS et al. Bi-annual surge of Crimean-Congo haemorrhagic fever (CCHF): a five-year experience. International Journal of Infectious Diseases, 2005, 9:37-42.

16. Athar MN et al. Crimean-Congo hemorrhagic fever outbreak in Rawalpindi, Pakistan, February 2002: contact tracing and risk assessment. American Journal of Tropical Medicine and Hygiene, 2005, 72:471-473.

17. Rai MA et al. Crimean-Congo hemorrhagic fever in Pakistan. Journal of medical virology, 2008, 80:1004-1006.

18. Mofleh JA, Ashgar RJ, Kakar RS. Nosocomial outbreak of Crimean-Congo hemorrhagic fever in Holy Family Hospital, Rawalpindi, Pakistan, 2010. Journal of Public Health and Epidemiology, 2013, 5(4):173-177.
19. Aradaib I et al. Multiple Crimean-Congo hemorrhagic fever virus strains are associated with disease outbreaks in Sudan, 2008-2009. PLoS Neglected Tropical Diseases, 2011, 5(5):e1159.

20. Elata A et al. A nosocomial transmission of Crimean-Congo hemorrhagic fever to an attending physician in north Kordufan, Sudan. Virology Journal, 2011, 8(1):303.

21. Aradaib I et al. Nosocomial outbreak of Crimean-Congo hemorrhagic fever, Sudan. Emerging Infectious Diseases, 2010, 16:837-839.

22. Onyango $\mathrm{CO}$ et al. Laboratory diagnosis of Ebola hemorrhagic fever during an outbreak in Yambio, Sudan, 2004. Journal of Infectious Diseases, 2007, 196(Suppl. 2):S193-S198.

23. World Health Organization. Global Alert and Response (GAR). Ebola haemorrhagic fever in South Sudan - update 8.6 July 2004 [webpage] (http://www.who.int/csr/ don/2004_07_06/en/index.html, accessed 9 May 2013).

24. World Health Organization. Global Alert and Response (GAR). Rift Valley fever in Yemen -update 4. 26 October 2000 [webpage] (http://www.who.int/csr/don/2000_10_26/en/index. html, accessed 9 May 2013).

25. Rift Valley fever, Saudi Arabia. August-October 2000. Weekly Epidemiological Record, 2000, 75:370-371.

26. Madani TA et al. Rift Valley fever epidemic in Saudi Arabia: epidemiological, clinical, and laboratory characteristics. Clinical Infectious Diseases, 2003, 37(8):1084-1092.

27. Hassan OA et al. The 2007 Rift Valley fever outbreak in Sudan. PLoS Neglected Tropical Diseases, 2011, 5(9):e1229.

28. World Health Organization. Global Alert and Response (GAR). Avian influenza - situation in Djibouti, 12 May 2006 [webpage] (http://www.who.int/csr/don/2006_05_12/en/index.html, accessed 9 May 2013).

29. World Health Organization. Global Alert and Response (GAR). Avian influenza-situation in Iraq- update 5.19September 2006 [webpage] (http://www.who.int/csr/don/2006_09_19/en/ index.html, , accessed 9 May 2013).

30. World Health Organization. Global Alert and Response (GAR). Avian influenza - situation in Pakistan - update 2. 3 April 2008 [webpage] (http://www.who.int/csr/don/2008_04_03/en/ index.html, accessed 9 May 2013).

31. World Health Organization. Influenza at the human-animal interface. Summary and assessment as of 26 April 2013. http://www.who.int/influenza/human_animal_interface/Influenza_Summary_IRA_HA_interface_26Apr13.pdf, accessed 9 May 2013).

32. New cases of avian influenza $\mathrm{A}(\mathrm{H} 5 \mathrm{~N} 1)$ in Egypt. Weekly Epidemiological Monitor, 2012, 6(15 and 16) (http://applications. emro.who.int/dsaf/epi/2013/Epi_Monitor_2013_6_15-16.pdf, accessed 9 May 2013).

33. World Health Organization. Eastern Mediterranean Regional Office. Report on Pandemic H1N1 and progress on the response. ( http://applications.emro.who.int/docs/RC_technical_papers_2011_inf_doc_7_14208.pdf, accessed 10 May 2013)

34. Formenty $\mathrm{P}$ et al. Human monkeypox outbreak caused by novel virus belonging to Congo Basin clade, Sudan, 2005. Emerging Infectious Diseases, 2010, 16:1539-1545.

35. Sandfly fever in Lebanon (July 2007-September 2007). Weekly Epidemiological Monitor, 2008, 1(5) (http://applications.emro. who.int/dsaf/epi/2008/Epi_Monitor_2008_1_5.pdf, accessed 9 May 2013).

36. Cabanel $\mathrm{N}$ et al. Plague outbreak in Libya, 2009, unrelated to plague in Algeria. Emerging Infectious Diseases, 2013, 19:230236. 
37. Madani TA. Alkhumra virus infection, a new viral hemorrhagic fever in Saudi Arabia. Journal of Infection, 2005, 51:91-97.

38. Madani TAet al. Alkhumra (Alkhurma) virus outbreak in Najran, Saudi Arabia: epidemiological, clinical, and laboratory characteristics. Journal of Infection, 2011, 62(1):67-76.

39. Memish Z et al Alkhumra haemorrhagic fever: case report and infection control details. British Journal of Biomedical Science, 2005, 62:37-39.

40. Zaki AM et al. Isolation of a novel coronavirus from a man with pneumonia in Saudi Arabia. New England Journal of Medicine, 2012, 367:1814-1820.

41. Malik M et al. Emergence of novel human coronavirus: public health implications in the Eastern Mediterranean Region. Eastern Mediterranean Health Journal, 2012, 18:1084-1085.

42. World Health Organization. Global Alert and Response (GAR). Novel coronavirus infection - update. 30 November 2012 [webpage] (www.who.int/csr/don/2012_11_30/en/index. html, accessed 9 May 2013).

43. World Health Organization. Global Alert and Response (GAR). Novel coronavirus infection - update. 26 March 2013 [webpage] (http://www.who.int/csr/don/2013_03_26/en/index. htm, accessed 9 May 2013).

44. McCloskey B et al. Applying lessons from SARS to a newly identified coronavirus. The Lancet Infectious Diseases, 13(5):384-385.

45. Ahmed QA, et al. Health risks at the Hajj. Lancet. 2006 Mar 25;367(9515):1008-15

46. Memish ZA, Venkatesh S, Ahmed QA. Travel epidemiology: the Saudi perspective. International Journal of Antimicrobial Agents, 2003, 21:96-101.

47. The Health Protection Agency (HPA) UK Novel Coronavirus Investigation team. Evidence of person-to-person transmission within a family cluster of novel coronavirus infections, United Kingdom, February 2013. Eurosurveillance, 2013, 18(11):pii 20427 (http://www.eurosurveillance.org/ViewArticle. aspx?Articleld=20427, accessed 9 May 2013).

48. World Health Organization. Interim surveillance recommendations for human infection with novel coronavirus as of 18 March 2013 (http://www.who.int/csr/disease/ coronavirus_infections/InterimRevisedSurveillanceRec-
ommendations_nCoVinfection_18Mar13.pdf, accessed 9 May 2013)

49. WHO Laboratory testing for novel coronavirus (Available from http://www.who.int/csr/disease/coronavirus_infections/en/ index.html, accessed 10 May 2013).

50. Pebody R, Zambon M, Watson J. Novel coronavirus: how much of a threat? BMJ, 2013, 346:f1301.

51. Core components of infection prevention and control programmes in health care. Geneva, World Health Organization, 2011 (Aidememoire). (http://www.who.int/csr/resources/publications/ AM_CoreCom_IPC.pdf, accessed 9 May 2013).

52. Cheng Y et al. Use of convalescent plasma therapy in SARS patients in Hong Kong. European Journal of Clinical Microbiology and Infectious Disease, 2005, 24(1):44-46.

53. Zhou B et al. Treatment with convalescent plasma for influenza A (H5N1) infection. New England Journal of Medicine, 2007, 357(14):1450-1451.

54. Hung IF et al. Convalescent plasma treatment reduced mortality in patients with severe pandemic influenza A (H1N1) 2009 virus infection. Clinical Infectious Diseases, 2011, 52(4):447-456.

55. International Health Regulations, 2005. Geneva, World Health Organization, 2005.

56. Tabbaa D. Emerging zoonoses: responsible communication with the media - lessons learned and future perspective. International Journal of Antimicrobial Agents, 2010, 36S:S80-S83.

57. Corman VM et al. Assays for laboratory confirmation of novel human coronavirus (hCoV-EMC) infections. Eurosurveillace, 2012, 17(49):pii 20334 (http://www.eurosurveillance.org/ ViewArticle.aspx?Articleld=20334, accessed 9 May 2013).

58. Reusken $\mathrm{C}$ et al. Specific serology for emerging human coronaviruses by protein microarray. Eurosurveillance, 2013;18(14):pii 20441. (http://www.eurosurveillance.org/ViewArticle. aspx?Articleld=20441, accessed 9 May 2013

59. Gould LH et al. An outbreak of yellow fever with concurrent chikungunya virus transmission in South Kordofan, Sudan, 2005. Transactions of the Royal Society of Tropical Medicine and Hygiene, 2008, 102(12):1247-1254.

60. Onyango CO et al. Yellow fever outbreak, southern Sudan, 2003. Emerging Infectious Diseases, 2004, 10(9):1668-1670. 